\title{
PENGARUH PEMAHAMAN HAK ASASI MANUSIA (HAM) TERHADAP SIKAP MENGHARGAI PENDAPAT ORANG LAIN PADA MAHASISWA PROGRAM STUDI PPKN FKIP UAD
}

\author{
Wiwik Okta Susilawati ${ }^{1}$, Ana Novitasari ${ }^{2}$, Gingga Prananda ${ }^{3}$, Lika Apreasta ${ }^{4}$, \\ Andiyanto ${ }^{5}$ \\ Universitas Dharmas Indonesia Sumatera Barat \\ Email: wiwikoktasusilawati@undhari.ac.id1, ananovitasari@undhari.ac.id2, \\ ginggaprananda@undhari.ac.id ${ }^{3}$, likapareasta@undhari.ac.id4, \\ andiyanto@undhari.ac.id ${ }^{5}$
}

\begin{abstract}
The formulation of the problem in this study is is there a meaning of understanding human rights towards other people's opinions? The purpose of this research is to see whether or not there is an understanding of human rights regarding the attitudes of other people's opinions. The research was conducted with a quantitative approach. The research sample consisted of 55 students of the PPKn FKIP UAD class of 2009-2014 who had taken the Human Rights and Democracy Education courses. The data was collected through a multiple choice test (multiple choice) to measure the variable understanding of human rights and a questionnaire to measure the variable of respect for other people's opinions. The data analysis method used was product display analysis and simple regression analysis. The results showed that Ho was rejected and Ha was accepted or stated that "there is an effect of understanding human rights on respect for others" based on the calculation of the coefficient of determination calculated as $8.4 \%$. This indicates that as much as $8.4 \%$ of changes in the attitude of respecting others who respect human rights.
\end{abstract}

Keywords: Understanding human rights, Respecting other people's opinions, Human rights education

\section{PENDAHULUAN}

\section{A. Latar Belakang}

Upaya Penegakan hak asasi manusia (HAM) merupakan rangkaian proses guna menjabarkan nilai, ide, cita-cita yang selanjutnya menjadi tujuan HAM. Tujuan HAM memuat nilai-nilai moral, yakni tentang nilai keadilan, kepastian, dan kemanfaatan. Hal ini mengandung pengertian bahwa upaya penegakan penghormatan, perlindungan, pemenuhan dan pemajuan atas HAM harus dilakukan pemerintah di Indonesia baik pada Tingkat Pusat, Provinsi maupun Kabupaten atau Kota. Sebagai bentuk kesanggupan upaya tersebut, telah disusun berbagai peraturan perundang-undangan yang mengatur tentang HAM, mulai dari UUD NRI 1945 sampai peraturan dibawahnya. Namun dalam perkembangannya hingga saat ini, harus diakui bahwa upaya penegakan HAM belum optimal karena masih menghadapi berbagai kendala. Berdasarkan data tentang hasil evaluasi pelaksanaan Rencana Aksi Nasional Hak Asasi Manusia Indonesia (RANHAM) 
2011-2014 sejauh ini menunjukkan sejumlah temuan antara lain: kurang optimalnya koordinasi antar lembaga pelaksana; kurangnya kesadaran masyarakat terhadap pemahaman HAM; kurang efektifnya mekanisme pemantauan, evaluasi dan pelaporan pelaksanaan RANHAM 2011-2014'.

Guna merealisasikan upaya penegakan HAM, pemerintah memandang perlu menyempurnakan dan melanjutkan RANHAM 2011-2014 ke dalam satu Rencana Aksi Nasional yang inklusif, yaitu RANHAM 2015-2019. RANHAM 2015-2019, khususnya pada bidang pendidikan dan peningkatan kesadaran masyarakat tentang HAM dapat dilakukan melalui penyebarluasan (sosialisasi/diseminasi) nilai HAM yang termuat dalam strategi ke empat RANHAM 2015. ${ }^{2}$ Namun pada faktanya sekarang ini masyarakat belum memiliki kesadaran untuk memahami HAM secara baik dan benar.

Keberhasilan pendidikan HAM di Perguruan Tinggi atau di masyarakat dapat dilihat dari terealisasinya tujuan pendidikan HAM. Tujuan dari adanya pendidikan HAM adalah apabila seseorang mampu memahami dan menerapkan nilai-nilai HAM dalam kehidupan bermasyarakat ${ }^{3}$. Selama Tahun 2015, Komnas HAM telah melihat banyak perkembangan positif dari adanya pendidikan HAM yang menghasilkan pemahaman HAM di masyarakat. Salah satu yang patut dicatat adalah penerapan nilai-nilai HAM yang dilakukan melalui promosi provinsi dan kabupaten atau kota layak HAM, pemahaman HAM oleh masyarakat yang menghasilkan gerakan untuk mendesak penyelesaian pelanggaran HAM masa lalu, hingga inisiatif pembentukan Komisi Kebenaran dan Rekonsiliasi di Aceh. ${ }^{4}$ Meskipun reputasi Indonesia di bidang HAM telah diakui sebagai salah satu yang cukup baik, bukan berarti Indonesia selesai dengan persoalan intoleransi, ketidakadilan, diskriminasi dan kesenjangan yang berujung pada pelanggaran HAM. Komnas HAM terus memantau dan mencermati berbagai permasalahan serius yang masih mengundang keprihatinan selama Tahun 2015. Namun pada kenyataannya yang masih menjadi titik kritis permasalahan HAM adalah gelombang

${ }^{1}$ Badriah, S. (2016, June 14). Rakor Implementasi RAN HAM 2016 dan Persiapan RAN HAM 2017 Retrieved March 3, 2017, from Kementerian Koordinator Bidang Pembangunan Manusia dan Kebudayaan: https://www.kemen-kopmk.go.id/artikel/rakor-implementasi-ran-ham-2016-dan-persiapan-ran-ham-2017.

2 Presiden Republik Indonesia. Peraturan Presiden Republik Indonesia Nomor 75 Tahun 2015 tentang Rencana Aksi Nasional Hak Asasi Manusia Tahun 2015-2019. (Jakarta: Sekretaris Kabinet RI Deputi Bidasng Politik, Hukum, dan Keamanan), h. 8.

3 Presiden Republik Indonesia. (2015). Lampiran Peraturan Presiden tentang Rencana Aksi Nasional Hak Asasi Manusia Tahun 2015-2019. (Jakarta: Deputi Bidang Politik, Hukum, dan Keamanan, 2015), h. 13.

${ }^{4}$ Laporan Tahunan 2015 Komnas HAM, Pemulihan Hak-Hak Korban Pelanggaran Hak Asasi Manusia, diterbitkan oleh Komisi Nasional Hak Asasi Manusia. (Jakarta,. dapat diakses melalui https://www.komnasham.go.id/files/20161008-laporan-tahunan-komnas-ham-2015- \$R0EQA7F.pdf, 2016), h. 18. 
intoleransi, baik yang ditujukan kepada kelompok-kelompok minoritas, maupun kelompok yang dipandang tidak sepaham. ${ }^{5}$

Salah satu bagian dari HAM adalah kebebasan menyampaikan pendapat. Pendapat merupakan usulan atau argumen yang disampaikan oleh tiap-tiap individu ${ }^{6}$. Setiap individu satu dengan lainnya tentu memiliki pendapat yang berbeda-beda dan perbedaan itulah yang harus mampu untuk dihormati dan dihargai supaya terjalin hubungan yang harmonis. Ketentuan mengeluarkan pendapat tersebut tercantum dalam Undang Undang Dasar Negara Republik Indonesia Tahun 1945 Pasal 28 yang berbunyi: "Kemerdekaan berserikat, dan berkumpul mengeluarkan pikiran dengan lisan dan tulisan dan sebagainya yang ditetapkan dengan undang-undang". ${ }^{7}$ Namun pada faktanya saat ini selama Tahun 2015 Komnas HAM menerima pengaduan dan melihat banyak sekali hambatan bagi warga negara dalam melaksanakan hak untuk menyampaikan pendapat di muka umum ${ }^{8}$. Sebagai contoh, Pemerintah DKI mengeluarkan Peraturan Gubernur DKI Jakarta tentang penyampaian pendapat. Peraturan Gubernur Nomor 228 Tahun 2015 tentang Kemerdekaan Menyampaikan Pendapat di Muka Umum ini menimbulkan persoalan karena hanya mengizinkan publik berunjuk rasa di tiga titik lokasi, yaitu Parkir Timur Senayan, Alun-alun Demokrasi DPR RI dan Monumen Nasional (Monas) ${ }^{9}$.

Pada Tahun 2015, Komnas HAM mencatat adanya pembatasan kebebasan berpendapat terhadap segala yang berkaitan dengan peristiwa 1965. Padahal semestinya setiap orang berhak atas kebebasan mempunyai dan mengeluarkan pendapat yang dalam hal ini merupakan kebebasan mempunyai pendapat dengan tidak mendapat gangguan. Namun faktanya saat ini terjadi pelarangan pemutaran film "Senyap" karya Joshua Oppenheimer di Universitas Sunan Kalijaga Yogyakarta oleh sekelompok pria bercadar pada 11 Maret 2015. Kemudian pada Agustus 2015 Temu Nasional Yayasan Penelitian Korban Pembunuhan 65 (YPKP 65) dibatalkan karena adanya intimidasi dan ancaman pembunuhan dari kelompok tertentu terhadap panitia. Peristiwa lainnya adalah pelarangan sesi pembahasan kasus 1965 pada acara Ubud Writers and Readers Festival (UWRF) 2015 yang digelar di Bali pada 28 Oktober-1 November 2015. Selain itu pada 16 Oktober 2015, majalah Lentera Merah yang dipublikasikan Universitas Kristen Satya Wacana di Salatiga, Jawa Tengah dilarang terbit. Majalah itu menyajikan liputan utama

${ }^{5}$ Laporan Tahunan 2015 Komnas HAM, Pemulihan Hak-Hak Korban Pelanggaran Hak Asasi Manusia, diterbitkan oleh Komisi Nasional Hak Asasi Manusia. (Jakarta, dapat diakses melalui https://www.komnasham.go.id/files/20161008-laporan-tahunan-komnas-ham-2015- \$R0EQA7F.pdf, 2016), h. 19.

${ }^{6}$ Nugraheni, I. C. Upaya Peningkatan Kemandirian Belajar dan Sikap Meng-hargai Pendapat Orang Lain Melalui Teknik Giving Ques-tions and Getting Answer dalam Pembelajaran IPS di SMP Negeri 1 Saptosari. (Yogyakarta: Fakultas Ilmu Sosial Universitas Negeri Yogyakarta, 2017), h. 18.

${ }^{7}$ Undang Undang Dasar Negara Republik Indonesia Tahun 1945

${ }^{8}$ Laporan Tahunan 2015 Komnas HAM, Pemulihan Hak-Hak Korban Pelanggaran Hak Asasi Manusia, diterbitkan oleh Komisi Nasional Hak Asasi Manusia. (Jakarta, dapat diakses melalui https://www.komnasham.go.id/files/20161008-laporan-tahunan-komnas-ham-2015- \$R0EQA7F.pdf, 2016), h. 35-36.

${ }^{9}$ Peraturan Gubernur Nomor 228 Tahun 2015 tentang Kemerdekaan Menyampaikan Pendapat di Muka Umum 
"Salatiga Kota Merah" yang bercerita soal pelanggaran HAM yang berat tahun 1965 di kota tersebut ${ }^{10}$.

Salah satu hak dasar warga negara adalah hak berpendapat dan kebebasan atas penyelenggaraan, pemenuhan, dan penegakan hak berpendapat itu sendiri. Hak tersebut merupakan bagian yang sangat penting dalam perjalanan penegakan HAM, mengingat upaya penegakan HAM yang bermuara kepada kebebasan HAM yang dari waktu ke waktu terus mengalami perkembangan. Namun, pada kenyataannya kebebasan HAM saat ini seringkali dipahami sebagai kebebasan tanpa batas sehingga berdampak kepada kebebasan tanpa batas dalam berdemokrasi yang berujung tidak berkualitasnya hasil demokrasi itu sendiri.

Masalah HAM memang tak pernah henti-hentinya menarik perhatian kalangan dunia. Masalah HAM adalah sesuatu hal yang sering kali dibicarakan dan dibahas terutama dalam era reformasi ini. Masalah HAM berkaitan dengan sikap menghargai pendapat orang lain. Sikap menghargai pendapat orang lain adalah suatu sikap di mana seseorang memiliki rasa hormat dan mampu menerima setiap perbedaan yang ada tanpa melihat siapa dan apa yang dimiliki oleh individu lain. Apabila setiap orang memiliki sikap menghargai pendapat orang lain maka akan terjalin kerukunan dan kenyamanan dalam setiap proses kehidupan. Namun pada kenyatannya saat ini masyarakat, khususnya mahasiswa kurang memiliki sikap menghargai orang lain.

\section{B. Rumusan Masalah}

Berdasarkan latar belakang yang telah dipaparkan di atas, maka terdapat beberapa permasalahan yang dapat diidentifikasi, yaitu sebagai berikut: kurang optimalnya upaya penegakan HAM di Indonesia, kurangnya kesadaran masyarakat terhadap pemahaman HAM, permasalahan gelombang intoleransi masih menjadi titik kritis pelanggaran HAM, adanya hambatan bagi warga negara dalam melaksanakan hak untuk menyampaikan pendapat di muka umum, adanya pembatasan kebebasan berpendapat terhadap segala yang berkaitan dengan peristiwa 1965, kesalahan pemahaman HAM yang sering dipahami sebagai kebebasan tanpa batas dan kurangnya sikap menghargai pendapat orang lain dikalangan mahasiswa. Agar permasalahan yang dikaji dapat dijawab secara mendalam dan tidak terlalu luas, maka penulis hanya membatasi masalah hanya pada rendahnya pemahaman HAM yang diasumsikan berpengaruh dengan tinggi rendahnya sikap menghargai pendapat orang lain, maka permasalahan yang dikaji dalam penelitian ini adalah adakah pengaruh pemahaman hak asasi manusia (HAM) terhadap sikap menghargai pendapat orang lain pada mahasiswa Program Studi PPKn FKIP UAD Angkatan Tahun 2009-2014.

${ }^{10}$ Laporan Tahunan 2015 Komnas HAM, Pemulihan Hak-Hak Korban Pelanggaran Hak Asasi Manusia, diterbitkan oleh Komisi Nasional Hak Asasi Manusia. (Jakarta, dapat diakses melalui https://www.komnasham.go.id/files/20161008-laporan-tahunan-komnas-ham-2015- \$R0EQA7F.pdf, 2016), h. 22. 


\section{METODE PENELITIAN}

Metode yang digunakan dalam penelitian ini adalah metode kuantitatif. Pemilihan metode kuantitatif dalam penelitian ini karena penelitian ini mengukur besaran pengaruh pemahaman mahasiswa tentang HAM terhadap sikap mereka untuk menghargai pendapat orang lain. Penelitian ini bermaksud untuk mendeteksi sejauh mana variasi-variasi pada suatu faktor, berhubungan dengan satu variasi atau lebih faktor lain berdasarkan koefisien korelasinya. Dengan kata lain, penelitian ini bermaksud mengungkapkan bentuk hubungan yang bersifat sebab akibat antar variabel yang diselidiki, yaitu pengaruh pemahaman HAM terhadap sikap menghargai pendapat orang lain.

Populasi adalah keseluruhan subjek penelitian. ${ }^{11}$ populasi bukan sekadar jumlah yang ada pada obyek atau subyek yang dipelajari, tetapi meliputi seluruh karakteristik atau sifat yang dimiliki oleh subyek atau obyek itu. ${ }^{12}$ Populasi pada penelitian ini adalah mahasiswa Program Studi Pendidikan Pancasila dan Kewarganegaraan Fakultas Keguruan dan Ilmu Pendidikan Universitas Ahmad Dahlan angkatan Tahun 2009-2014 yang telah mengambil mata kuliah Pendidikan HAM dan Demokrasi yang aktif sebanyak 123 orang.

Sampel adalah sebagian atau wakil dari populasi yang akan diteliti. Teknik pengambilan sampling yang digunakan dalam penelitian ini adalah probability sampling, yaitu memberikan peluang yang sama pada setiap anggota populasi untuk menjadi sampel. Pengambilan sampel dilakukan secara acak (simple random sampling). ${ }^{13}$ Simple random sampling adalah pengambilan anggota sampel dari populasi dilakukan secara acak tanpa memperhatikan strata yang ada dalam populasi itu. ${ }^{14}$ Penentuan jumlah sampel pada penelitian ini mengunakan rumus Slovin. Sampel dalam penelitian ini adalah 55,157 orang sehingga dibulatkan menjadi 55 orang, dengan mengambil sampel secara acak tanpa memperhatikan strata.

Variabel bebas (independen) merupakan variabel yang mempengaruhi atau yang menjadi sebab perubahannya atau timbulnya variabel terikat (dependen). Variabel bebas dalam penelitian ini adalah pemahaman HAM sebagai variabel X. Variabel terikat (dependen) merupakan variabel yang dipengaruhi atau yang menjadi akibat, karena adanya variabel bebas. Variabel terikat da-lam penelitian ini adalah sikap menghargai pendapat orang lain sebagai variabel Y. Teknik pengumpulan data yang digunakan dalam penelitian ini, adalah tes, angket atau kuesioner, dan dokumentasi. Penelitian ini menggunakan dua instrumen pengumpulan data, yaitu: lembar tes dan angket.

${ }^{11}$ Suharsimi, A. Prosedur Penelitian Suatu Pen-dekatan Praktik. (Jakarta: PT. Rineka Cipta, 2017), h. 173 .

12 Sugiyono. Metode Penelitian Pendidikan: Pendekatan Kuantitatif, Kualitatif, dan R\&D. (Bandung: Alfabeta, 2015), h. 117.

${ }^{13}$ Suharsimi, A. Prosedur Penelitian Suatu Pen-dekatan Praktik. (Jakarta: PT. Rineka Cipta, 2017), h. 131.

${ }^{14}$ Sugiyono. Metode Penelitian Pendidikan: Pendekatan Kuantitatif, Kualitatif, dan R\&D. (Bandung: Alfabeta, 2015), h. 120. 


\section{KAJIAN TEORI}

\section{A. Pemahaman Hak Asasi Manusia}

Pemahaman berasal dari kata paham yang artinya mengerti benar dalam suatu hal. Pemahaman merupakan kemampuan seseorang untuk menguasai (mengerti, memahami). ${ }^{15}$ Sedangkan menurut Sudijono mengartikan pemahaman sebagai kemampuan seseorang untuk mengerti, mengetahui atau memahami sesuatu dan dapat melihatnya dari berbagai segi. ${ }^{16}$ Peserta didik dikatakan paham jika peserta didik tersebut mampu memberikan penjelasan atau uraian yang lebih rinci dengan menggunakan katakatanya sendiri. Pemahaman merupakan jenjang kemampuan berpikir yang setingkat lebih tinggi dari ingatan dan hafalan. Definisi dari pemahaman terlebih lagi didukung oleh Winkel dan Mukhtar yang semakin menguatkan dalam pemahaman materi yang dijelaskan sebagai berikut: ${ }^{17}$

Pemahaman materi adalah kemampuan seseorang untuk menangkap makna dan arti dari bahan/materi yang dipelajari, yang dinyatakan dengan menguraikan isi pokok dari suatu bacaan atau mengubah data yang disajikan dalam bentuk tertentu ke bentuk yang lain.

Kemudian pemahaman materi menurut Anas tidak mengalami suatu perbedaan, namun semakin menguatkan adanya kemampuan untuk menggunakan pengetahuan yang sudah diingat lebih kurang sama dengan yang sudah diajarkan dan sesuai dengan maksud penggunaannya ${ }^{18}$. Definisi klasik dan menggejala dalam pemaknaan HAM yang sering dipakai dan dikutip adalah: ${ }^{19}$

A human right by definition is a universal moral right, something which all men, everywhere, at all times ought to have, something of which no one may deprived without a grave affront to justice, something which is owing to every human being simply because he [she] is human.

Dari definisi di atas dan sejumlah definisi lain yang diberikan dalam mencermati HAM, pemahaman atas HAM selanjutnya disebut sebagai berkarakter universal (untuk semua orang, waktu dan tempat), dimiliki oleh semua manusia. Dari sisi karakter ini saja sejumlah persoalan dan gugatan atas HAM kemudian mengemuka. Pertama tentang makna dan aplikasi universalitas HAM. Kedua, benarkah itu dapat dimiliki dan dilakukan oleh semua orang jika suatu sistem politik tidak memberi ruang gerak yang memadai.

Dari berbagai pendapat di atas, indikator pemahaman hak asasi manusia (HAM) pada dasarnya sama, yaitu dengan memahami sesuatu berarti seseorang dapat

${ }^{15}$ Depdiknas. Kamus Besar Bahasa Indonesia Edisi Keempat. (Jakarta: PT. Gramedia Pustaka, 2018), h. 1103.

${ }^{16}$ Sudjono, A. Pengantar Evaluasi Pendidikan. (Jakarta: Raja Grafindo Persada, 2016), h. 50.

${ }^{17}$ Sudaryono. Dasar-dasar Evaluasi Pembelajaran. (Yogyakarta: Graha Ilmu, 2012), h. 44.

${ }^{18}$ Anas, Y. Manajemen Pembelajaran dalam Instruksi Pendidikan. (Yogyakarta: IRCiSol, 2019), h. 50 .

${ }^{19}$ Prajarto, K.K. Hak Asasi Manusia (HAM) di Indonesia menuju Democratic Governances. (Jurnal Ilmu Sosial dan Ilmu Politik, 8(3), 2015), h. 294. 
menafsirkan, menerjemahkan, memparafrasakan, menggambarkan, mengklasifikasi, mencontohkan, mengilustrasikan, mengkategorikan, merangkum, menggeneralisasi-kan, mengabstraksikan, menyimpulkan, mengekstrapolasi, menginterpolasi, memprediksi, mem-bandingkan, mencocokkan, dan menjelaskan (untuk semua orang, waktu dan tempat), dimiliki oleh semua manusia. Indikator tersebut menunjukkan bahwa pemahaman mengandung makna lebih luas atau lebih dalam dari pengetahuan. Dengan pengetahuan seseorang belum tentu memahami sesuatu dari yang dipelajari. Sedangkan dengan pemahaman seseorang tidak hanya sekadar menghapal sesuatu yang dipelajari, tetapi juga mempunyai kemampuan untuk menangkap makna dari yang dipelajari secara lebih mendalam dan mampu memahami konsep dari pelajaran tersebut.

Berdasarkan pendapat yang disampaikan oleh beberapa ahli di atas, pemahaman hak asasi manusia (HAM) yang dimaksudkan dalam penelitian ini adalah suatu proses mengkonstruksi makna dari pesan-pesan pembelajaran, baik yang bersifat lisan, tulisan atau gratif yang disampaikan melalui pengajaran dengan kegiatan menafsirkan konsep HAM dari berbagai sudut pandang, mencontohkan bentuk-bentuk pe-langgaran HAM, mengklasifikasikan konsep HAM, merangkum sejarah HAM, menyimpulkan keterhubungan HAM dan demokrasi, mem-bandingkan konsep HAM Barat dan HAM Islam, dan menjelaskan konsep dasar HAM.

\section{B. Sikap Menghargai Pendapat Orang Lain}

Menurut Kamus Besar Bahasa Indonesia istilah menghargai berarti tuntutan setiap orang agar menghormati, mengindahkan, memuliakan, dan menjunjung tinggi pendapat dan keyakinan orang lain. ${ }^{20}$ Secara istilah Fatchurochman mendefinisikan kata menghargai sebagai memberikan harga atau memberikan penilaian yang baik. Dengan dihargai, seseorang akan merasa diperhatikan. ${ }^{21}$ Semakin baik penghargaan yang diberikan, maka seseorang akan tumbuh dengan semaik baik pula. Sebaliknya semakin buruk penghargaan yang diberikan kepada seseorang, maka semakin buruk pula pertumbuhan mentalnya.

Setiap orang hendaknya sadar bahwa seorang harus bisa dan mau menerima orang lain apa adanya, dalam arti tidak ada diskriminasi. Setiap orang harus mampu menerima seseorang dengan tidak membedakan suku, agama, bahasa, ras, jenis kelamin, dan bangsanya. Setiap orang patut dan layak untuk dihargai dan dihormati. Menghargai orang lain berarti memperlakukan orang lain secara baik dan benar, baik lewat perkataan maupun perbuatan. ${ }^{22}$

Definisi sikap menghargai orang lain ditemukan pula oleh Arliani bahwa sikap saling menghargai merupakan bentuk pengendalian diri, orang yang dapat menghargai

${ }^{20}$ Depdiknas. Kamus Besar Bahasa Indonesia Edisi Keempat. (Jakarta: PT. Gramedia Pustaka, 2018), h. 525.

${ }^{21}$ Fatchurochman, N. Teaching with Love: Pendekatan Cinta dan Akhlak Mulia dalam Pembelajaran. (Jakarta: Senama Sejahtera Utama, 2018), h. 102.

${ }^{22}$ Panjaitan, H. Pentingnya Menghargai Orang Lain. (Jurnal Humaniora, 5(1), April 2014), h. 95. 
orang lain tidak akan menyakiti siapapun, baik dalam bentuk perkataan (lisan maupun tulisan) maupun perbuatan, ia tahu berterima kasih dan memahami orang lain. ${ }^{23}$ Seseorang yang menghargai orang lain tidak akan pernah menyalahkan atau mempermalukannya di depan orang lain. Jika perbuatan seseorang tidak sesuai dengan yang diharapkan, maka sebaiknya tidak serta merta mengatakan bahwa perbuatan tersebut salah. Sebab itu akan berpengaruh negatif padanya, ia akan merasa malu dan merasa tidak dihargai.

Kemudian pendapat lain menurut Nugraheni sikap menghargai pendapat orang lain adalah suatu sikap di mana seseorang memiliki rasa hormat dan mampu menerima setiap perbedaan yang ada tanpa melihat siapa dan apa yang dimiliki oleh individu lain. ${ }^{24}$ Apabila setiap peserta didik memiliki sikap menghargai pendapat orang lain maka akan terjalin kerukunan dan kenyamanan dalam setiap proses pembela-jaran. Agama juga telah mengajarkan kepada umat manusia untuk hidup saling hornat-menghormati, menghargai, saling mengasihi kepada sesama makhluk ciptaan Tuhan tanpa terkecuali, karena manusia itu pada dasarnya tidak bisa hidup sendiri (makhluk sosial).

Berdasarkan beberapa pendapat di atas, sikap menghargai pendapat orang lain dalam penelitian ini diartikan sebagai suatu reaksi seseorang yang berbentuk kebiasaan atau tingkah laku secara positif dan negatif terhadap konsep secara menyeluruh untuk merespon objek yang berupa pendapat orang lain dan mampu membawa dan menuju ke tingkah laku yang nyata yaitu dimana seseorang memperlakukan orang lain secara baik dan benar, baik lewat perkataan maupun perbuatan sehingga tidak akan menyakiti siapapun serta mampu menghormati dan menjunjung tinggi pendapat orang lain, mampu mengindahkan setiap perkataan dan keyakinan orang lain, tidak menganggap dirinya yang paling benar, memperlakukan orang lain secara baik dan benar, serta mampu menerima setiap perbedaan.

\section{HASIL PENELITIAN DAN PEMBAHASAN}

A. Hasil Penelitian

1. Data Hasil Penelitian Pemahaman Hak Asasi Manusia (X)

Berikut ini tabel penyajian data hasil penelitian pemahaman hak asasi manusia $(X)$.

Tabel 1. Data Hasil Penelitian Pemahaman Hak Asasi Manusia (X)

\begin{tabular}{|c|c|c|c|c|c|c|c|c|c|c|c|c|c|c|c|c|c|c|}
\hline \multirow[t]{2}{*}{ No } & \multicolumn{17}{|c|}{ Butir Soal } & \\
\hline & 1 & 2 & 3 & 4 & 5 & 6 & 7 & 8 & 9 & 10 & 11 & 12 & 13 & 14 & 15 & 16 & 17 & Total \\
\hline 1 & 1 & 0 & 1 & 1 & 1 & 0 & 1 & 0 & 1 & 0 & 1 & 1 & 0 & 1 & 1 & 1 & 1 & 12 \\
\hline
\end{tabular}

${ }^{23}$ Arliani, E. Mengembangkan Sikap Saling Menghargai melalui Pembelajaran Matematika: Upaya Memperbaiki Karakter Bangsa. Seminar Nasional Matematika dan Pendidikan Matematika FMIPA UNY. (Yogykarta: Pendidikan Matematika FMIPA UNY, 2017), h. 997.

${ }^{24}$ Nugraheni, I. C. Upaya Peningkatan Kemandirian Belajar dan Sikap Meng-hargai Pendapat Orang Lain Melalui Teknik Giving Ques-tions and Getting Answer dalam Pembelajaran IPS di SMP Negeri 1 Saptosari. (Yogyakarta: Fakultas Ilmu Sosial Universitas Negeri Yogyakarta, 2017), h. 19. 


\begin{tabular}{|c|c|c|c|c|c|c|c|c|c|c|c|c|c|c|c|c|c|c|}
\hline 2 & 1 & 1 & 1 & 1 & 1 & 1 & 1 & 0 & 1 & 1 & 0 & 1 & 1 & 1 & 1 & 1 & 1 & 15 \\
\hline 3 & 1 & 0 & 1 & 0 & 0 & 1 & 1 & 1 & 1 & 1 & 1 & 1 & 0 & 1 & 1 & 1 & 1 & 13 \\
\hline 4 & 1 & 1 & 1 & 1 & 1 & 1 & 1 & 1 & 0 & 1 & 1 & 1 & 1 & 0 & 1 & 1 & 1 & 15 \\
\hline 5 & 1 & 1 & 1 & 1 & 1 & 1 & 1 & 1 & 1 & 1 & 1 & 1 & 1 & 1 & 1 & 1 & 1 & 17 \\
\hline 6 & 1 & 1 & 1 & 1 & 1 & 0 & 1 & 0 & 1 & 1 & 1 & 1 & 1 & 1 & 1 & 1 & 0 & 14 \\
\hline 7 & 1 & 1 & 1 & 1 & 1 & 1 & 1 & 1 & 1 & 1 & 1 & 1 & 1 & 1 & 1 & 1 & 1 & 17 \\
\hline 8 & 1 & 1 & 1 & 1 & 0 & 1 & 0 & 1 & 1 & 0 & 1 & 1 & 1 & 1 & 1 & 1 & 1 & 14 \\
\hline 9 & 0 & 1 & 1 & 1 & 1 & 1 & 1 & 1 & 1 & 1 & 1 & 1 & 1 & 1 & 1 & 1 & 1 & 16 \\
\hline 10 & 1 & 1 & 0 & 1 & 1 & 1 & 1 & 1 & 1 & 1 & 1 & 1 & 1 & 1 & 1 & 1 & 1 & 16 \\
\hline 11 & 1 & 1 & 0 & 0 & 1 & 1 & 1 & 0 & 1 & 1 & 0 & 1 & 0 & 1 & 1 & 1 & 0 & 11 \\
\hline 12 & 1 & 0 & 0 & 0 & 1 & 1 & 0 & 0 & 1 & 1 & 1 & 0 & 0 & 0 & 0 & 0 & 1 & 7 \\
\hline 13 & 1 & 1 & 1 & 1 & 1 & 1 & 1 & 1 & 1 & 1 & 1 & 1 & 1 & 0 & 1 & 1 & 1 & 16 \\
\hline 14 & 1 & 0 & 0 & 1 & 1 & 1 & 1 & 1 & 1 & 1 & 1 & 1 & 1 & 1 & 1 & 1 & 1 & 15 \\
\hline 15 & 0 & 1 & 1 & 0 & 0 & 0 & 1 & 0 & 0 & 1 & 1 & 1 & 1 & 1 & 1 & 1 & 1 & 11 \\
\hline 16 & 1 & 1 & 1 & 1 & 1 & 1 & 1 & 1 & 1 & 1 & 1 & 1 & 1 & 1 & 1 & 1 & 1 & 17 \\
\hline 17 & 1 & 1 & 1 & 1 & 1 & 1 & 1 & 1 & 1 & 1 & 1 & 1 & 1 & 1 & 1 & 1 & 1 & 17 \\
\hline 18 & 1 & 1 & 1 & 0 & 0 & 0 & 1 & 1 & 1 & 1 & 1 & 0 & 0 & 1 & 1 & 1 & 1 & 12 \\
\hline 19 & 1 & 1 & 1 & 1 & 1 & 1 & 1 & 1 & 1 & 1 & 0 & 1 & 1 & 1 & 1 & 1 & 1 & 16 \\
\hline 20 & 0 & 1 & 1 & 1 & 1 & 1 & 1 & 1 & 1 & 1 & 1 & 1 & 1 & 1 & 0 & 1 & 1 & 15 \\
\hline 21 & 1 & 1 & 1 & 1 & 1 & 1 & 1 & 1 & 1 & 1 & 1 & 1 & 1 & 1 & 1 & 1 & 1 & 17 \\
\hline 22 & 1 & 1 & 1 & 1 & 1 & 1 & 1 & 1 & 1 & 1 & 1 & 1 & 1 & 1 & 1 & 1 & 1 & 17 \\
\hline 23 & 1 & 1 & 1 & 1 & 1 & 1 & 0 & 1 & 1 & 1 & 1 & 1 & 1 & 1 & 1 & 1 & 1 & 16 \\
\hline 24 & 1 & 0 & 1 & 1 & 1 & 1 & 1 & 1 & 1 & 1 & 1 & 1 & 1 & 1 & 1 & 1 & 1 & 16 \\
\hline 25 & 1 & 1 & 1 & 1 & 1 & 1 & 1 & 1 & 1 & 1 & 0 & 1 & 1 & 1 & 1 & 1 & 0 & 15 \\
\hline
\end{tabular}

Tabel 1 di atas menunjukkan hasil penelitian pemahaman HAM sebagai variabel X. berdasarkan hasil tersebut, peneliti menggunakannya sebagai salah satu syarat untuk melanjutkan analisis penghitungan korelasi product moment dan dilanjutkan dengan analisis regresi sederhana untuk menjawab tujuan penelitian. Analisis penghitungan korelasi product moment dan analisis regresi sederhana dilakukan dengan memasukkan semua skor total dari setiap skor jawaban responden ke dalam program komputer SPSS Statistics for windows versi 16.0.

\section{Data Hasil Penelitian Sikap Menghargai Pendapat Orang Lain (Y)}

Berikut ini tabel penyajian data hasil penelitian sikap menghargai pendapat orang lain (Y)

Tabel 2. Data Hasil Penelitian Sikap Menghargai Pendapat Orang Lain (Y)

\begin{tabular}{|c|c|c|c|c|c|c|c|c|c|c|c|c|c|c|c|c|c|c|c|c|}
\hline \multirow{2}{*}{ No } & \multicolumn{19}{|c|}{ Butir Soal } & \multirow{2}{*}{ Total } \\
\hline & 1 & 2 & 3 & 4 & 5 & 6 & 7 & 8 & 9 & 10 & 11 & 12 & 13 & 14 & 15 & 16 & 17 & 18 & 19 & \\
\hline 1 & 4 & 3 & 3 & 4 & 3 & 3 & 3 & 3 & 4 & 4 & 3 & 4 & 3 & 3 & 4 & 3 & 3 & 4 & 3 & 64 \\
\hline 2 & 4 & 3 & 3 & 4 & 4 & 3 & 3 & 4 & 4 & 4 & 4 & 3 & 3 & 4 & 3 & 4 & 4 & 4 & 4 & 69 \\
\hline 3 & 4 & 4 & 4 & 4 & 4 & 4 & 4 & 4 & 4 & 4 & 4 & 4 & 4 & 4 & 4 & 4 & 4 & 4 & 4 & 76 \\
\hline
\end{tabular}




\begin{tabular}{|l|l|l|l|l|l|l|l|l|l|l|l|l|l|l|l|l|l|l|l|l|}
\hline 4 & 4 & 4 & 4 & 4 & 3 & 3 & 3 & 3 & 3 & 3 & 4 & 4 & 4 & 4 & 4 & 4 & 4 & 4 & 4 & 70 \\
\hline 5 & 4 & 4 & 4 & 4 & 3 & 3 & 3 & 3 & 4 & 4 & 2 & 2 & 4 & 4 & 4 & 3 & 4 & 3 & 4 & 66 \\
\hline 6 & 4 & 3 & 4 & 4 & 4 & 4 & 4 & 3 & 4 & 4 & 4 & 4 & 4 & 3 & 3 & 4 & 3 & 4 & 4 & 71 \\
\hline 7 & 4 & 4 & 3 & 4 & 3 & 3 & 3 & 3 & 3 & 3 & 4 & 3 & 3 & 3 & 4 & 4 & 4 & 3 & 4 & 65 \\
\hline 8 & 4 & 3 & 4 & 4 & 3 & 3 & 4 & 3 & 4 & 4 & 4 & 4 & 3 & 4 & 4 & 4 & 3 & 4 & 4 & 70 \\
\hline 9 & 4 & 4 & 4 & 4 & 4 & 4 & 4 & 4 & 4 & 4 & 4 & 4 & 4 & 4 & 4 & 4 & 4 & 4 & 4 & 76 \\
\hline 10 & 3 & 3 & 3 & 4 & 3 & 3 & 3 & 3 & 3 & 3 & 4 & 3 & 3 & 3 & 3 & 4 & 4 & 3 & 3 & 61 \\
\hline 11 & 3 & 3 & 3 & 3 & 3 & 3 & 3 & 4 & 3 & 3 & 3 & 3 & 3 & 3 & 3 & 3 & 3 & 3 & 3 & 58 \\
\hline 12 & 4 & 4 & 3 & 4 & 3 & 4 & 3 & 3 & 3 & 3 & 4 & 3 & 3 & 3 & 4 & 3 & 3 & 4 & 3 & 64 \\
\hline 13 & 4 & 4 & 4 & 4 & 4 & 4 & 4 & 4 & 3 & 3 & 3 & 3 & 4 & 4 & 4 & 4 & 4 & 4 & 4 & 72 \\
\hline 14 & 4 & 4 & 4 & 4 & 4 & 3 & 3 & 3 & 4 & 4 & 4 & 4 & 3 & 3 & 3 & 4 & 4 & 4 & 4 & 70 \\
\hline 15 & 3 & 3 & 3 & 3 & 3 & 3 & 3 & 3 & 3 & 3 & 3 & 3 & 3 & 3 & 3 & 3 & 3 & 3 & 3 & 57 \\
\hline 16 & 4 & 4 & 4 & 4 & 3 & 3 & 4 & 4 & 4 & 3 & 4 & 4 & 4 & 3 & 4 & 3 & 4 & 3 & 4 & 70 \\
\hline 17 & 3 & 3 & 3 & 3 & 3 & 3 & 4 & 4 & 4 & 4 & 3 & 3 & 4 & 4 & 3 & 3 & 4 & 4 & 3 & 65 \\
\hline 18 & 4 & 4 & 4 & 4 & 4 & 4 & 4 & 4 & 4 & 4 & 4 & 4 & 4 & 4 & 4 & 4 & 4 & 4 & 4 & 76 \\
\hline 19 & 4 & 4 & 4 & 4 & 4 & 4 & 3 & 4 & 3 & 4 & 4 & 4 & 4 & 4 & 3 & 4 & 3 & 4 & 4 & 72 \\
\hline 20 & 3 & 4 & 4 & 4 & 4 & 3 & 3 & 3 & 4 & 4 & 3 & 4 & 3 & 4 & 3 & 4 & 4 & 4 & 4 & 69 \\
\hline 21 & 4 & 4 & 3 & 3 & 3 & 3 & 4 & 4 & 4 & 4 & 4 & 4 & 4 & 4 & 3 & 3 & 4 & 3 & 4 & 69 \\
\hline
\end{tabular}

Tabel 2 di atas menunjukkan data hasil sikap menghargai pendapat orang lain sebagai variabel Y. berdasarkan data tersebut, peneliti kemudian menggunakannya untuk mendukung data dari pemahaman HAM (X). Setelah data hasil penelitian pemahaman HAM (X) dan data hasil penelitian sikap menghargai pendapat orang lain (Y) lengkap, maka peneliti dapat melanjutkan analisis penghitungan korelasi product moment dan analisis regresi sederhana untuk menjawab tujuan penelitian, karena analisis penghitungan korelasi product moment dan analisis regresi sederhana membutuhkan data dari variabel X (pemahaman HAM) dan variabel Y (sikap menghargai pendapat orang lain).

Analisis penghitungan korelasi product moment dan analisis regresi sederhana dilakukan dengan memasukkan semua skor total dari setiap skor jawaban responden, baik semua skor total dari variabel X (pemahaman HAM) maupun semua skor total variabel Y (sikap menghargai pendapat orang lain) ke dalam program komputer SPSS Statistics for windows versi 16.0. Penelitian ini melakukan analisis korelasi product moment dan analisis regresi sederhana dengan memasukkan semua prediktor ke dalam analisis sekaligus, atau biasa disebut dengan metode enter. Sehingga apabila hanya salah satu variabel saja yang dimasukkan ke dalam program komputer SPSS Statistics for windows versi 16.0 maka tidak akan bisa mendapatkan jawaban dari hasil korelasi product moment dan regresi sederhana serta tidak bisa menjawab tujuan penelitian.

\section{B. Analisis Data Penelitian}

Analisis data yang dilakukan adalah dengan pengujian hipotesis. Hipotesis merupakan jawaban sementara terhadap rumusan masalah penelitian, di mana rumusan 
masalah penelitian telah dinyatakan dalam bentuk kalimat pernyataan. Dikatakan sementara, karena jawaban yang diberikan baru didasarkan pada teori yang relevan, belum pada fakta-faka empiris yang diperoleh melalui pengumpulan data. Oleh karena itu, jawaban sementara ini harus diuji kebenarannya secara empirik. ${ }^{25}$ Apakah data yang terkumpul mendukung hipotesis yang diajukan atau menolak hipotesis yang diajukan. Dalam hal penelitian ini, ada dua hipotesis yang diajukan, yaitu hipotesis nihil (Ho) dan hipotesis alternatif (Ha). Hipotesis nihil (Ho) adalah hipotesis yang menyatakan bahwa tidak ada pengaruh antara variabel $\mathrm{X}$ terhadap variabel $\mathrm{Y}$. Sedangkan hipotesis alternatif (Ha) adalah hipotesis yang menyatakan bahwa ada pengaruh antara variabel $X$ terhadap variabel Y. Adapun hipotesis yang diuji dalam penelitian ini adalah sebagai berikut :

$\mathrm{Ha}=$ Ada pengaruh pemahaman HAM terhadap sikap menghargai pendapat orang lain

Ho $=$ Tidak ada pengaruh pemahaman HAM terhadap sikap menghargai pendapat orang lain

Berikut ini analisis data dalam penelitian ini, yaitu sebagai berikut:

\section{Penghitungan koefisien korelasi product moment}

Penghitungan ini dilakukan dengan cara mengkorelasikan antara seluruh data pemahaman HAM dengan sikap menghargai pendapat orang lain. Untuk menghitung koefisien korelasi product moment, peneliti menggunakan bantuan program komputer SPSS Statistics for win-dows versi 16.0. Berdasarkan hasil penghitungan menggunakan bantuan program SPSS Statistics for windows versi 16.0 dengan rumus product moment, diketahui bahwa koefisien korelasi antara pemahaman HAM dengan sikap menghargai pendapat orang lain adalah 0,289. Selanjutnya koe-fisien korelasi tersebut diban-dingkan dengan r-tabel untuk $n=55$ adalah sebesar 0,266. Maka dapat diketahui bahwa r-hitung > r-tabel. Dapat diambil kesimpulan dari perhitungan tersebut, yaitu ada hubungan yang positif dan signifikan antara pemahaman HAM dengan sikap menghargai pendapat orang lain. Sesuai dengan tabel pedoman Sugiyono mengenai pedoman untuk memberikan interpretasi koefisien korelasi ${ }^{26}$ hasil dari r-hitung $=0,289$ mengenai hubungan variabel $\mathrm{X}$ dan variabel $\mathrm{Y}$, maka tingkat hubungannya adalah rendah yaitu antara 0,200 - 0,399. Berikut ini tabel 3. tentang ringkasan hasil koefisien korelasi product moment

2. Tabel 3. Ringkasan Hasil Koefisien Korelasi Product Moment

\begin{tabular}{|l|l|l|l|}
\hline \multicolumn{3}{|c|}{ Correlations } \\
\hline & & $\begin{array}{c}\text { pemahaman_ } \\
\text { HAM }\end{array}$ & $\begin{array}{c}\text { sikap_menghargai_o } \\
\text { rang_lain }\end{array}$ \\
\hline pemahaman & Pearson Correlation & 1 & $.289^{*}$ \\
\hline
\end{tabular}

${ }^{25}$ Sugiyono. Metode Penelitian Pendidikan: Pendekatan Kuantitatif, Kualitatif, dan R\&D. (Bandung: Alfabeta, 2015), h. 96.

${ }^{26}$ Sugiyono. Metode Penelitian Pendidikan: Pendekatan Kuantitatif, Kualitatif, dan R\&D. (Bandung: Alfabeta, 2015), h. 257. 


\begin{tabular}{|l|l|r|r|}
\cline { 2 - 4 } & Sig. (2-tailed) & & .032 \\
\cline { 2 - 4 } & $\mathrm{N}$ & 55 & 55 \\
\hline $\begin{array}{l}\text { sikap_meng } \\
\text { hargai_oran } \\
\text { g_lain }\end{array}$ & Pearson Correlation & $.289^{*}$ & 1 \\
\cline { 2 - 4 } & Sig. (2-tailed) & .032 & 55 \\
\cline { 2 - 4 } & $\mathrm{N}$ & 55 & \\
\hline \multirow{2}{*}{ *. Correlation is significant at the 0.05 level (2- tailed). } & \\
\hline
\end{tabular}

\section{Uji F}

Pengujian ini dilakukan untuk mengetahui apakah data mempunyai hubungan yang linear atau tidak, yaitu antara data variabel pemahaman HAM de-ngan sikap menghargai pendapat orang lain. Pengujian ini dilakukan dengan menggunakan bantuan program SPSS Statistics for windows versi 16.0. Diketahui bahwa nilai F-hitung adalah sebesar 4,831. Selanjutnya hasil tersebut dibandingkan dengan dengan nilai F-tabel untuk df1= $\mathrm{k}-1=2-1=1$, df2=n-k=55-2=53 yaitu sebesar 4,02. Maka dapat diketahui bahwa Fhitung > F-tabel dengan tingkat signifikan di bawah 0,05 yaitu 0,032 sehingga dapat diambil kesimpulan bahwa ada hubungan yang linear antara pemahaman HAM dengan sikap menghargai pendapat orang lain. Berikut ini tabel 4. tentang ringkasan hasil Uji $F$ variabel pemahaman HAM terhadap variabel sikap menghargai pendapat orang lain.

Tabel 4. tentang Ringkasan Hasil Uji F Variabel Pemahaman HAM terhadap Variabel Sikap Menghargai Pendapat Orang Lain

\begin{tabular}{|c|c|c|c|c|c|c|}
\hline \multicolumn{7}{|c|}{ ANOVA $^{b}$} \\
\hline \multicolumn{2}{|c|}{ Model } & $\begin{array}{l}\text { Sum of } \\
\text { Squares }\end{array}$ & df & Mean Square & $\mathbf{F}$ & Sig. \\
\hline \multirow[t]{3}{*}{1} & Regression & 130.390 & 1 & 130.390 & 4.831 & $.032^{\mathrm{a}}$ \\
\hline & Residual & 1430.337 & 53 & 26.987 & & \\
\hline & Total & 1560.727 & 54 & & & \\
\hline \multicolumn{4}{|c|}{$\begin{array}{l}\text { a. Predictors: (Constant), } \\
\text { Pemahaman_HAM }\end{array}$} & & & \\
\hline \multicolumn{6}{|c|}{ b. Dependent Variable: Sikap_Menghargai_Pendapat_Orang_Lain } & \\
\hline
\end{tabular}

\section{Ujit}

Pengujian ini dilakukan untuk mengetahui apakah variabel independen (pemahaman HAM) berhubungan dengan variabel dependen (sikap menghargai pendapat orang lain). Adapun pengujiannya dengan mengguna-kan bantuan program SPSS Statistics for windows versi 16.0. Diketahui bahwa nilai t-hitung adalah 2,198 dan t-tabel pada taraf signifikan $5 \%$ untuk $\mathrm{df}=(\mathrm{n}-\mathrm{k})=(55-2)=53$ yaitu sebesar 1,674. Maka dapat dinyatakan bahwa t-hitung > t-tabel. Jadi dapat diambil kesimpulan Ho ditolak dan Ha 
diterima atau dinyatakan "variabel pemahaman HAM $(\mathrm{X})$ berpengaruh terhadap variabel sikap menghargai pendapat orang lain (Y)". Terdapat pengaruh signifikan berarti hubungan itu dapat digeneralisasikan. Berikut ini tabel 5. Tentang Ringkasan hasil Uji t variabel pemahaman HAM terhadap variabel sikap menghargai pendapat orang lain.

Tabel 5. Ringkasan hasil Uji t Variabel Pemahaman HAM terhadap Variabel Sikap Menghargai Pendapat Orang Lain

\begin{tabular}{|c|c|c|c|c|c|c|}
\hline \multicolumn{7}{|c|}{ Coefficients $^{\mathrm{a}}$} \\
\hline \multirow{2}{*}{\multicolumn{2}{|c|}{ Model }} & \multicolumn{2}{|c|}{$\begin{array}{l}\text { Unstandardized } \\
\text { Coefficients }\end{array}$} & \multirow{2}{*}{$\begin{array}{c}\begin{array}{c}\text { Standardized } \\
\text { Coefficients }\end{array} \\
\text { Beta }\end{array}$} & \multirow{2}{*}{$\mathbf{T}$} & \multirow{2}{*}{ Sig. } \\
\hline & & B & Std. Error & & & \\
\hline \multirow[t]{2}{*}{1} & (Constant) & 60.943 & 3.125 & & 19.505 & .000 \\
\hline & $\begin{array}{l}\text { Pemahaman } \\
\text { _HAM }\end{array}$ & .496 & .226 & 289 & 2.198 & .032 \\
\hline & $\begin{array}{l}\text { endent Var } \\
\text { Mengharg }\end{array}$ & & & & & \\
\hline
\end{tabular}

\section{Perhitungan Regresi Sederhana}

Penghitungan regresi sederhana ini digunakan untuk melakukan prediksi seberapa jauh perubahan nilai variabel Y (sikap menghargai pendapat orang lain) apabila nilai variabel X (pemaha-man HAM) dirubah. Perhitungan analisis regeresi sederhana ini dilakukan dengan menggunakan bantuan program SPSS Statistics for windows versi 16.0. Diketahui bahwa hasil perhitungan analisis regresi sederhana adalah sikap menghargai pendapat orang lain $=60,943+0,496$ pemahaman HAM. Sehingga dapat diambil kesimpulan sebagai berikut: (1) Nilai konstanta sebesar 60,943 artinya pemahaman HAM sama dengan nol, maka sikap menghargai pendapat orang lain sama dengan 60,943. (2) Koefisien regresi variabel sikap menghargai pendapat orang lain 0,496 artinya apabila pemahaman HAM dinaikkan satu satuan maka akan menaikkan sikap menghargai pendapat orang lain sebesar 0,496 dan sebaliknya apabila pemahaman HAM diturunkan sebesar satu satuan maka akan menurunkan sikap menghargai pendapat orang lain sebesar 0,496. Berikut ini tabel 6. tentang Hasil analisis regresi sederhana.

Tabel 6. Hasil Analisis Regresi Sederhana

\begin{tabular}{|c|c|c|c|c|c|c|}
\hline \multicolumn{7}{|c|}{ Coefficients $^{\mathrm{a}}$} \\
\hline \multirow{2}{*}{\multicolumn{2}{|c|}{ Model }} & \multicolumn{2}{|c|}{$\begin{array}{l}\text { Unstandardized } \\
\text { Coefficients }\end{array}$} & \multirow{3}{*}{\begin{tabular}{|c|}
$\begin{array}{c}\text { Standardized } \\
\text { Coefficients }\end{array}$ \\
Beta
\end{tabular}} & \multirow{3}{*}{$\begin{array}{l}\mathbf{T} \\
19.505\end{array}$} & \multirow{3}{*}{$\begin{array}{r}\text { Sig. } \\
.000\end{array}$} \\
\hline & & \multirow{2}{*}{\begin{tabular}{|l|} 
B \\
60.943
\end{tabular}} & \multirow{2}{*}{\begin{tabular}{r|} 
Std. Error \\
3.125
\end{tabular}} & & & \\
\hline 1 & (Constant) & & & & & \\
\hline & $\begin{array}{l}\text { Pemahaman } \\
\text { _HAM }\end{array}$ & .496 & .226 & .289 & 2.198 & .032 \\
\hline
\end{tabular}


a. Dependent Variable:

Sikap_Menghargai_Pendapat_Orang_Lain

\section{Perhitungan Koefisien Determinasi}

Perhitungan koefisien determi-nasi digunakan untuk mengetahui seberapa besar persentase pengaruh semua varian variabel inde-penden (pemahaman HAM) terhadap variabel dependen (sikap menghargai pendapat orang lain). Perhitungan ini dilakukan dengan mengunakan bantuan program SPSS Statistics for windows versi 16.0. Diketahui bahwa hasil perhitungan koefisien determinasi ditunjukkan dengan besarnya ni-lai $\mathrm{R}$ Squere, yaitu: 0,084. Dengan demikian dapat disimpulkan bahwa sebesar 8,4\% perubahan-perubahan sikap menghargai pendapat orang lain dipengaruhi oleh pemahaman HAM. Sedangkan sisanya sebesar 91,6\% perubahan terjadi pada sikap menghargai pendapat orang lain dipengaruhi oleh faktor lain, diantaranya pengaruh lingkungan keluarga, kebudayaan, pergaulan, teman sebaya, faktor emosional, kehidupan masyarakat sekitar dan lain-lain. Berikut ini tabel 7. tentang hasil perhitungan koefisien determinasi.

Tabel 7. Hasil Perhitungan Koefisien Determinasi

\begin{tabular}{|l|c|r|c|c|}
\hline \multicolumn{5}{|c|}{ Model Summary } \\
\hline Model & R & R Square & $\begin{array}{c}\text { Adjusted R } \\
\text { Square }\end{array}$ & $\begin{array}{c}\text { Std. Error of the } \\
\text { Estimate }\end{array}$ \\
\hline 1 & $.289^{\mathrm{a}}$ & .084 & .066 & 5.19495 \\
\hline \multicolumn{7}{|c|}{ a. Predictors: (Constant), Pemahaman_HAM } \\
\hline
\end{tabular}

\section{Pembahasan}

Tujuan dari penelitian ini adalah untuk mengetahui ada atau tidaknya pengaruh pemahaman HAM terhadap sikap menghargai pendapat orang lain. Dari data penelitian yang telah dikumpulkan dan dianalisis, peneliti kemudian melakukan pembahasan mengenai hasil penelitian. Untuk mengetahui pengaruh antara variabel pemahaman HAM terhadap variabel sikap menghargai pendapat orang lain menggunakan analisis korelasi dan regresi sederhana.

Pemahaman HAM pada penelitian ini diartikan sebagai suatu proses mengkonstruksi makna dari pesan-pesan pembelajaran, baik yang bersifat lisan, tulisan atau gratif yang disampaikan melalui pengajaran dengan kegiatan menafsirkan konsep HAM dari berbagai sudut pandang, mencontohkan bentuk-bentuk pe-langgaran HAM, mengklasifikasikan konsep HAM, merangkum sejarah HAM, menyimpulkan keterhubungan HAM dan demokrasi, membandingkan konsep HAM Barat dan HAM Islam, dan menjelaskan konsep dasar HAM. Penelitian ini melakukan pengumpulan data pemahaman HAM menggunakan tes pilihan ganda (multiple choise) dengan soal sejumlah 22 pertanyaan untuk mengukur validitas data. Dari 22 pertanyaan yang diberikan kepada 30 sampel dari populasi, maka mendapatkan 17 pertanyaan valid dan 5 pertanyaan tidak valid. Selanjutnya mengukur reliabilitas, hasil r-hitung instrumen 
pemahaman HAM sebesar 0,819 dan r-tabel sebesar 0,361, maka r-hitung lebih besar dari pada r-tabel. Kesimpulannya instrumen pemahaman HAM adalah signifikan dan reliabel. Berikut ini tabel 8. tentang ringkasan hasil uji validitas tes pemahaman HAM dan tabel 9. tentang hasil uji reliabilitas instrumen tes pemahaman HAM.

Tabel 8. Ringkasan Hasil Uji Validitas Tes Pemahaman HAM

\begin{tabular}{|c|c|c|c|}
\hline $\begin{array}{l}\text { No. } \\
\text { Item }\end{array}$ & r-hitung & r-tabel & Keterangan \\
\hline 1 & 0,408 & 0,361 & Valid \\
\hline 2 & 0,384 & 0,361 & Valid \\
\hline 3 & 0,514 & 0,361 & Valid \\
\hline 4 & 0,382 & 0,361 & Valid \\
\hline 5 & 0,487 & 0,361 & Valid \\
\hline 6 & 0,435 & 0,361 & Valid \\
\hline 7 & 0,306 & 0,361 & Invalid \\
\hline 8 & 0,578 & 0,361 & Valid \\
\hline 9 & 0,614 & 0,361 & Valid \\
\hline 10 & 0,405 & 0,361 & Valid \\
\hline 11 & 0,636 & 0,361 & Valid \\
\hline 12 & 0,521 & 0,361 & Valid \\
\hline 13 & 0,487 & 0,361 & Valid \\
\hline 14 & 0,437 & 0,361 & Valid \\
\hline 15 & 0,360 & 0,361 & Invalid \\
\hline 16 & $-0,003$ & 0,361 & Invalid \\
\hline 17 & 0,220 & 0,361 & Invalid \\
\hline 18 & 0,342 & 0,361 & Invalid \\
\hline 19 & 0,573 & 0,361 & Valid \\
\hline 20 & 0,752 & 0,361 & Valid \\
\hline 21 & 0,487 & 0,361 & Valid \\
\hline 22 & 0,706 & 0,361 & Valid \\
\hline
\end{tabular}

Tabel 9. Hasil Uji Reliabilitas Instrumen Tes Pemahaman HAM

\begin{tabular}{|c|c|c|}
\hline Variabel & Cronbach's Alpha & N of Items \\
\hline $\mathrm{X}$ & .819 & 22 \\
\hline
\end{tabular}

Sikap menghargai pendapat orang lain pada penelitian ini diartikan sebagai suatu reaksi seseorang yang berbentuk kebiasaan atau tingkah laku secara positif dan negatif terhadap konsep secara menyeluruh untuk merespon objek yang berupa pendapat orang lain dan mampu membawa dan menuju ke tingkah laku yang nyata yaitu dimana seseorang memperlakukan orang lain secara baik dan benar, baik lewat perkataan maupun perbuatan sehingga tidak akan menyakiti siapapun serta mampu menghormati dan menjunjung tinggi pendapat orang lain, mampu mengindahkan setiap perkataan dan keyakinan orang lain, tidak menganggap dirinya yang paling benar, memperlakukan orang lain secara baik dan benar, serta mampu menerima setiap perbedaan. Penelitian ini melakukan pengumpulan data sikap menghargai pendapat orang lain menggunakan 
angket dengan soal sejumlah 20 pernyataan dan diberikan kepala 30 sampel yang berasal dari populasi. Pernyataan tersebut untuk menguji validitas data. Dari 20 pernyataan tersebut, maka mendapatkan 19 pernyataan valid dan 1 pernyataan tidak valid. Selanjutnya mengukur reliabilitas, dengan hasil r-hitung instrumen sikap menghargai pendapat orang lain sebesar 0,887 dan r-tabel sebesar 0,361, maka r-hitung lebih besar dari pada r-tabel. Kesimpulannya instrumen sikap menghargai pendapat orang lain adalah signifikan dan reliabel. Berikut ini tabel 10. tentang ringkasan hasil uji validitas angket sikap menghargai pendapat orang lain dan tabel 11. tentang hasil uji reliabilitas instrumen angket sikap menghargai pendapat orang lain.

Tabel 10. Ringkasan Hasil Uji Validitas Angket Sikap Menghargai Pendapat Orang Lain

\begin{tabular}{|r|c|c|c|}
\hline $\begin{array}{r}\text { No. } \\
\text { Item }\end{array}$ & r-hitung & r-tabel & Keterangan \\
\hline 1 & 0,347 & 0,361 & Invalid \\
\hline 2 & 0,435 & 0,361 & Valid \\
\hline 3 & 0,435 & 0,361 & Valid \\
\hline 4 & 0,706 & 0,361 & Valid \\
\hline 5 & 0,466 & 0,361 & Valid \\
\hline 6 & 0,518 & 0,361 & Valid \\
\hline 7 & 0,533 & 0,361 & Valid \\
\hline 8 & 0,590 & 0,361 & Valid \\
\hline 9 & 0,705 & 0,361 & Valid \\
\hline 10 & 0,688 & 0,361 & Valid \\
\hline 11 & 0,466 & 0,361 & Valid \\
\hline 12 & 0,410 & 0,361 & Valid \\
\hline 13 & 0,547 & 0,361 & Valid \\
\hline 14 & 0,761 & 0,361 & Valid \\
\hline 15 & 0,690 & 0,361 & Valid \\
\hline 16 & 0,620 & 0,361 & Valid \\
\hline 17 & 0,706 & 0,361 & Valid \\
\hline 18 & 0,677 & 0,361 & Valid \\
\hline 19 & 0,641 & 0,361 & Valid \\
\hline 20 & 0,407 & 0,361 & Valid \\
\hline & & & \\
\hline
\end{tabular}

Tabel 11. Hasil Uji Reliabilitas Instrumen Angket Sikap Menghargai Pendapat Orang Lain

\begin{tabular}{|c|c|c|}
\hline Variabel & Cronbach's Alpha & N of Items \\
\hline Y & .887 & 20 \\
\hline
\end{tabular}

Penelitian ini melakukan perhitungan regresi sederhana dengan bantuan program SPSS Statistics for windows versi 16.0, hasilnya dapat diketahui sebagai berikut.

1. Hasil uji t untuk $\mathrm{df}=(\mathrm{n}-\mathrm{k})=(55-2)=53$ yaitu sebesar 1,674 dan taraf signifikan $=5 \%$ sehingga diketahui nilai t-hitung $(2,198)>\mathrm{t}$-tabel $(1,674)$, berarti Ho ditolak dan Ha diterima atau dinyatakan "ada pengaruh pemahaman HAM terhadap sikap menghargai pendapat orang lain”. 
2. Berdasarkan perhitungan regresi sederhana sikap menghargai pendapat orang lain $=60,943+0,496$ pemahaman HAM. Apabila pemahaman HAM sama dengan nol, maka sikap menghargai pendapat orang lain sama dengan 60,943. Jika pemahaman HAM dinaikkan sebesar satu satuan maka akan menaikkan sikap menghargai pendapat orang lain sebesar 0,496 dan sebaliknya apabila pemahaman HAM diturunkan sebesar satu satu maka akan menurunkan sikap menghargai pendapat orang lain sebesar 0,496.

3. Berdasarkan perhitungan koefisien determinasi didapatkan hasil perhitungan sebesar 8,4\%. Hal ini menyatakan bahwa sebesar 8,4\% perubahan-perubahan sikap menghargai pendapat orang lain dipengaruhi oleh pemahaman HAM sehingga dosen mata kuliah Pendidikan HAM dan Demokrasi disarankan untuk menekankan arti penting pemahaman HAM.

Signifikan adalah kemampuan untuk menggeneralisasikan dengan kesalahan tertentu. Adanya pengaruh signifikan berarti pengaruh itu dapat digeneralisasikan. Sedangkan pengaruh yang positif apabila terjadi perubahan antara pemahaman HAM menjadi lebih baik maka akan diikuti oleh perubahan sikap menghargai pendapat orang lain dan sebaliknya apabila terjadi perubahan pemahaman HAM menjadi menurun maka akan diikuti sikap menghargai pendapat orang lain yang menurun juga. Jadi hasil analisis menunjukkan bahwa apabila pemahaman HAM akan berdampak positif bagi sikap menghargai pendapat orang lain.

Hasil penelitian ini mendukung pendapat Gagne \& Berliner mengenai teori belajar behavioristik bahwa "perubahan tingkah laku sebagai hasil dari pengalaman". Dari pendapat Gagne \& Berliner tersebut, belajar merupakan akibat adanya interaksi antara stimulus atau respons. Seseorang dianggap telah belajar sesuatu jika dia dapat menunjukkan perubahan tingkah laku/sikapnya. Menurut teori ini, dalam belajar yang penting adalah input yang berupa stimulus dan output yang berupa respons. Stimulus adalah apa saja yang diberikan pendidikan kepada pebelajar, sedangkan respons berupa reaksi atau tanggapan pebelajar terhadap stimu-lus yang diberikan oleh pendidik tersebut. ${ }^{27}$ Dengan demikian menurut teori ini, seseorang yang telah diberikan stimulus berupa materi HAM akan menghasilkan suatu input berupa pengetahuan serta pemahaman mahasiswa secara kognitif terkait dengan HAM melalui proses pembelajaran HAM \& Demokrasi yang kemudian akan ditanggapi atau direspons oleh pebelajar atau mahasiswa melalui perubahan sikap yang mengarah pada capaian pembelajaran HAM berupa sikap menghargai pendapat orang lain sebagai output.

\footnotetext{
${ }^{27}$ Thobroni. M. Belajar \& Pembelajaran: Teori dan Praktik. (Yogyakarta: Ar-Ruzz Media, 2016) h. 55-
} 56. 


\section{SIMPULAN}

Secara keseluruhan diketahui bahwa pemahaman HAM memiliki pengaruh terhadap sikap menghargai pendapat orang lain. Hal ini dapat diketahui sebagai berikut.

1. Hasil uji t untuk df $=(\mathrm{n}-\mathrm{k})=(55-2)=53$ yaitu sebesar 1,674 dan taraf signifikan $=$ $5 \%$ sehingga diketahui nilai t-hitung $(2,198)>$ t-tabel $(1,674)$, berarti Ho ditolak dan Ha diterima atau dinyatakan "ada pengaruh pemahaman HAM terhadap sikap menghargai pendapat orang lain.

2. Berdasarkan perhitungan regresi sederhana sikap menghargai pendapat orang lain $=60,943+0,496$ pemahaman HAM. Apabila pemahaman HAM sama dengan nol, maka sikap meng-hargai pendapat orang lain sama dengan 60,943. Jika pemahaman HAM dinaikkan sebesar satu satuan maka akan menaikkan sikap menghargai pendapat orang lain sebesar 0,496 dan sebaliknya apabila pemahaman HAM diturunkan sebesar satu satu maka akan menurunkan sikap meng-hargai pendapat orang lain sebesar 0,496 .

3. Berdasarkan perhitungan koefisien determinasi didapatkan hasil perhitungan sebesar $8,4 \%$. Hal ini menyatakan bahwa sebesar 8,4\% perubahan-perubahan sikap menghargai pendapat orang lain dipengaruhi oleh pemahaman HAM.

\section{DAFTAR PUSTAKA}

Anas, Y. 2019. Manajemen Pembelajaran dalam Instruksi Pendidikan. Yogyakarta: IRCiSol.

Arliani, E. 2017. Mengembangkan Sikap Saling Menghargai melalui Pembelajaran Matematika: Upaya Memperbaiki Karakter Bangsa. Seminar Nasional Matematika dan Pendidikan Matematika FMIPA UNY. Yogykarta: Pendidikan Matematika FMIPA UNY.

Badriah, S. (2016, June 14). Rakor Implementasi RAN HAM 2016 dan Persiapan RAN HAM 2017 Retrieved March 3, 2017, from Kementerian Koordinator Bidang Pembangunan Manusia dan Kebudayaan: https://www.kemenkopmk.go.id/artikel/rakor-implementasi-ran-ham-2016-dan-persiapan-ran-ham-2017.

Depdiknas. 2018. Kamus Besar Bahasa Indonesia Edisi Keempat. Jakarta: PT. Gramedia Pustaka.

Fatchurochman, N. 2018. Teaching with Love: Pendekatan Cinta dan Akhlak Mulia dalam Pembelajaran. Jakarta: Senama Sejahtera Utama.

Laporan Tahunan 2015 Komnas HAM. 2016. Pemulihan Hak-Hak Korban Pelanggaran Hak Asasi Manusia, diterbitkan oleh Komisi Nasional Hak Asasi Manusia. (Jakarta, 
dapat diakses melalui https://www.komnasham. go.id/files/20161008-laporantahunan-komnas-ham-2015-\$R0EQA7F.pdf,2016).

Nugraheni, I. C. 2017. Upaya Peningkatan Kemandirian Belajar dan Sikap Meng-hargai Pendapat Orang Lain Melalui Teknik Giving Ques-tions and Getting Answer dalam Pembelajaran IPS di SMP Negeri 1 Saptosari. Yogyakarta: Fakultas Ilmu Sosial Universitas Negeri Yogyakarta.

Panjaitan, H. 2014. Pentingnya Menghargai Orang Lain. Jurnal Humaniora, 5(1), April 2014.

Peraturan Gubernur Nomor 228 Tahun 2015 tentang Kemerdekaan Menyampaikan Pendapat di Muka Umum.

Prajarto, K.K. 2015. Hak Asasi Manusia (HAM) di Indonesia menuju Democratic Governances. Jurnal Ilmu Sosial dan Ilmu Politik, 8(3).

Presiden Republik Indonesia. 2015. Peraturan Presiden Republik Indonesia Nomor 75 Tahun 2015 tentang Rencana Aksi Nasional Hak Asasi Manusia Tahun 2015-2019. Jakarta: Sekretaris Kabinet RI Deputi Bidasng Politik, Hukum, dan Keamanan.

Presiden Republik Indonesia. 2015. Lampiran Peraturan Presiden tentang Rencana Aksi Nasional Hak Asasi Manusia Tahun 2015-2019. Jakarta: Deputi Bidang Politik, Hukum, dan Keamanan.

Sudjono, A. 2016. Pengantar Evaluasi Pendidikan. Jakarta: Raja Grafindo Persada, 2016.

Sudaryono. 2012. Dasar-dasar Evaluasi Pembelajaran. Yogyakarta: Graha Ilmu, 2012.

Suharsimi, A. 2017. Prosedur Penelitian Suatu Pen-dekatan Praktik. Jakarta: PT. Rineka Cipta.

Sugiyono. 2015. Metode Penelitian Pendidikan: Pendekatan Kuantitatif, Kualitatif, dan R\&D. Bandung: Alfabeta.

Thobroni. M. 2016. Belajar \& Pembelajaran: Teori dan Praktik. Yogyakarta: Ar-Ruzz Media.

Undang Undang Dasar Negara Republik Indonesia Tahun 1945 